\title{
THE INFLUENCE OF CROP ROTATION AND NUTRITION REGIME IN WINTER WHEAT ON THE PHYTOMASS REMAINS AND THE DEPOSITS OF WEED SEEDS REMAINED IN THE GROUND
}

\author{
Gheorghe-Emil BANDICI ${ }^{1}$, ILEANA ARDELEAN ${ }^{1}$ \\ ${ }^{1}$ University of Oradea, Faculty of Environment Protection, Department of Agricultural, Oradea, Romania \\ Corresponding author: University of Oradea, Faculty of Environment Protection, Department of Agricultural, 26 Magheru Str., zip \\ code: 410048, Oradea, Romania, tel.: 004059412550, fax. 0040259416274, e-mail: gbandici@yahoo.com
}

Key words: crop rotation, phytomass, dry weigh, root, stub, accumulation, weed seeds.

Summary

An important problem refers to soil weeds seed bank with special reference to brown luvic soils and relationship between vegetal remains $($ roots + stub) and nutrition regime - crop rotation plant. A great number of seeds can be found in first 20 centimeters of soil (plowing layer). This fact causes a high weeds density, which has a negative effect on the cultivated plants leading to partial or total crop loss.

\section{INTRODUCTION}

The natural law fertilisation, the acid reaction and internal slow drainage are the main characteristics of brown soils (8).

If we add to these the low degree of structure $(27-36 \%)$, the temporary excess of humidity and the big deposits of weed seeds in the soil, we get an almost complete picture of the restrictive production factors on brown soils in our country (6).

Related to these above, the specialized literature $(3,4)$ underline the fact that biochemical processes which take place in the non-structured and slightly aired soils are too lean and they could lead to the increase of the content of some substances (fulvic acids) which affect the clay (5). To prevent these phenomena from happenning, the soils must be aired when the $\mathrm{C} / \mathrm{N}$ ratio, accessible, reaches the normal values (40 - 70), the microbian activity is well stimulated and has favourable effects upon all the chemical transformations in the soil and finally increases the fertility degree of soils, like the brown ones (7).

These are some aspects about the improvement of the supplying process of the soil with nutritional elements which are necessary for the growth and development of the cultivated plants.

Another important problem is the one reffering to the general deposits of weed seeds remained in the ground and especially the brown soils. A great number of weed seeds up to the depth of the arable layer $(0-20$ $\mathrm{cm}$ ), leads implicitly to a high degree of weed growing which can determine a series of negative effects upon plants and can partially or totally compromise the culture (1).

Brown luvic soils are characterized by acid reaction, low internal drainage, low structuring level (27$36 \%$ ), temporary water excess and high content weed seed bank. All these factors are considered to be limited in Romania (2).

An important problem refers to soil weeds seed bank with special reference to brown luvic soils. A great number of seeds can be found in first 20 centimeters of soil (plowing layer). This fact causes a high weeds density which have a negative effect on the cultivated plants leading to partial or total crop loss (9).

\section{MATERIALS AND METHODS}

A multifactorial experiment (subdivided plats) was set up in the period 2008-2009 at Agricultural Research and Development Station (A.R.D.S.) Oradea, Romania on soils characterized by temporary excess of humidity as brown luvic soils are having in view the realization of total phytomass as function of phenophase, crop rotation plant and nutrition regime.

The experimental design was polyfactorial in subdivides stands using as factors interaction: forerunner plant, fertilization level and phenophase. As biological material, the Delia race of wheat was employed.

Total phytomass and separately every plants part were weighted in the laboratory. The results were analyzed with ANOVA (analysis of variance), the phytomass being expressed as dry weight/10 plants.

\section{RESULTS AND DISCUSSIONS}

The influence of crop rotation plant, nutrition regime on the amount of organic matter (stub + roots) accumulated in soil in winter wheat culture is presented in table 1. 
Data from table1 show that in wheat monoculture, with 1.9 t/ha total dry weight accumulated in soil, the cultivation of wheat after corn or pea in 2 years, 3 years respectively crop rotation, determined an increment of organic matter accumulated in soil with 15.8-52.6\%. Highest dry matter quantity was found in wheat cultivated in combination with a crop rotation plant as pea of $2.9 \mathrm{t} / \mathrm{ha}$, at values with $1 \mathrm{t} / \mathrm{ha}$ higher as compared to monoculture and even to short rotation (W-C) with $0.3 \mathrm{t} / \mathrm{ha}$.

Highest contribution to phytomass accumulation in soil had wheat stub with $85.7 \%$ of total amount as compared to root lower contribution of $14.3 \%$.

This quantity of dry weight as roots contribution (14.3\%) not negligible if taking into account the more rapid decomposition in soil of roots as compared to stub which contains more cellulose and decomposes slower, in soil under the attack of decomposing microorganisms.

In what concerns fertilization level, data from table 1, show that mineral or mixed fertilization doubles the amount of total dry weight accumulated in soil (2.7 and $2.8 \mathrm{t} / \mathrm{ha}$, respectively) as compared to the unfertilized alternative of $1.4 \mathrm{t} / \mathrm{ha}$. In this case, stub realizes a greater amount of total phytomass in d.w. (85.5\%) as compared to roots' contribution of only $14.5 \%$.

Table 1

The influence of crop rotation plant and nutrition regime on vegetal remains accumulation in soil (stubble + roots) in wheat cultivated on brown luvic soils, Oradea (Romania) 2008-2009

\begin{tabular}{|c|c|c|c|c|c|}
\hline \multirow{3}{*}{ Factor under study } & \multicolumn{4}{|c|}{ Phytomass in d.w. } & \multirow{3}{*}{$\begin{array}{c}\text { Diff. } \pm \\
\text { t/ha }\end{array}$} \\
\hline & \multirow{2}{*}{$\begin{array}{c}\text { Root } \\
\text { t/ha }\end{array}$} & \multirow{2}{*}{$\begin{array}{c}\text { Stub } \\
\text { t/ha }\end{array}$} & \multicolumn{2}{|c|}{ Total d.w. } & \\
\hline & & & $\mathrm{t} / \mathrm{ha}$ & $\%$ & \\
\hline \multicolumn{6}{|c|}{ a. Crop rotation plant } \\
\hline Wheat - monoculture (Mt) & 0.4 & 1.5 & 1.9 & 100 & - \\
\hline Corn $(\mathrm{W}-\mathrm{C})$ & 0.3 & 1.9 & 2.2 & 115.8 & +0.3 \\
\hline Pea $(P-W-C)$ & 0.3 & 2.6 & 2.9 & 152.6 & +1.0 \\
\hline Average (\%) & $14.3 \%$ & $85.7 \%$ & $100 \%$ & - & - \\
\hline \multicolumn{6}{|c|}{ b. Nutrition regime } \\
\hline $\mathbf{N}_{0} \mathbf{P}_{0}(\mathbf{M t})$ & 0.4 & 1.0 & 1.4 & 100 & - \\
\hline $\mathbf{N}_{120} \mathbf{P}_{80}$ & 0.3 & 2.4 & 2.7 & 192.8 & +1.3 \\
\hline $\mathrm{N}_{100} \mathrm{P}_{80}+10$ t/ha manure & 0.3 & 2.5 & 2.8 & 200.0 & +1.4 \\
\hline Media (\%) & $14.5 \%$ & $85.5 \%$ & $100 \%$ & - & - \\
\hline
\end{tabular}

The influence of crop rotation plant and fertilization level a weed seed bank in soil, in wheat cultivated on brown luvic soils, $0-20 \mathrm{~cm}$ deep, is presented in the following table (table 2):

In what concerns weeds seed bank in soil, in wheat cultivated on brown luvic soils, in corroboration with crop rotation plant, fertilization level and their interaction, one can conclude (based on data from table 2). following:

As a succession of the analysis that we made and distinguished in the table 2, we can specify the

Weeds' seed numbers in soil reached highest values in crop rotation when wheat was cultivated after pea, 39.642 seeds $/ \mathrm{m}^{2}$, followed by wheat monoculture with 32.722 seeds $/ \mathrm{m}^{2}$.

Lowest number of weed seeds $/ \mathrm{m}^{2}$ was found in wheat cultivated after corn, of $29.976 \mathrm{seeds} / \mathrm{m}^{2}$. The explanation lies in the nature of corn cultivation which implies tillage that destroys an important amount of weeds. This reduces infestation source of soil with weed seeds as compared to wheat cultivated after pea that do not need tillage.

Accordingly, weed seeds source is greater, seed bank provision, also, in plots where wheat was cultivated after pea.

It is worth to remark that numbers in weeds of dicotyledons are greater as compared to weed species of monocotyledons (table 2) regardless to crop rotation plant employed (dicotyledons - 57.1\%, monocotyledons $42.9 \%$ ).

Table 2 shows a strong influence manifested in case of created agrofund on weed seeds bank from soil. As compared to unfertilized alternative $\left(22.042\right.$ weed seeds $\left./ \mathrm{m}^{2}\right)$, mineral fertilization and mixed fertilization determined the raise of weed seeds in soil to 37.570 and 42.728 weed seeds $/ \mathrm{m}^{2}$, respectively. In the case of fertilization level, weed seeds proportion is greater for dicotyledons $(61 \%)$ both in fertilized or fertilized alternatives. 
The influence of crop rotation plant and nutrition regime a weed seed bank in soil, in wheat cultivated on brown luvic soils, $0-20$ cm deep, Oradea (Romania) 2008-2009

\begin{tabular}{|c|c|c|c|c|c|}
\hline \multirow{3}{*}{ Investigated factors } & \multicolumn{4}{|c|}{ Weed seeds $/ \mathrm{m}^{2}$} & \multirow[t]{3}{*}{$\begin{array}{l}\text { Diff.土 } \\
\text { nr./m² }\end{array}$} \\
\hline & \multirow{2}{*}{$\begin{array}{c}\text { Monocotyledons } \\
\mathrm{nr} . / \mathrm{m}^{2} \\
\end{array}$} & \multirow{2}{*}{$\begin{array}{c}\text { Dicotyledons } \\
\mathrm{nr} . / \mathrm{m}^{2} \\
\end{array}$} & \multicolumn{2}{|c|}{ Total weeds } & \\
\hline & & & $\mathrm{nr} . / \mathrm{m}^{2}$ & $\%$ & \\
\hline \multicolumn{6}{|c|}{$\begin{array}{c}\text { a. Crop rotation plant } \\
\end{array}$} \\
\hline Wheat - monoculture (Mt) & 13787 & 18935 & 32722 & 100 & - \\
\hline Corn $(\mathrm{W}-\mathrm{C})$ & 11993 & 17983 & 29976 & 91.6 & -2746 \\
\hline Pea $(\mathbf{P}-\mathbf{W}-\mathbf{C})$ & 18120 & 21521 & 39642 & 121.1 & +6920 \\
\hline Average (\%) & 42.9 & 57.1 & 100 & - & - \\
\hline \multicolumn{6}{|c|}{ b. Nutrition regime } \\
\hline N0P0 (Mt) & 5137 & 16905 & 22042 & 100 & - \\
\hline N120P80 & 17363 & 20207 & 37570 & 170.4 & +15528 \\
\hline $\mathrm{N100P80}+10$ t/ha manure & 17450 & 25278 & 42728 & 193.8 & +20686 \\
\hline Media $(\%)$ & 39.0 & 61.0 & 100 & - & - \\
\hline
\end{tabular}

The data that we presented in table 3 , therefore the realized experiments, allaws us to sustain the following affirmations:

- weeds $/ \mathrm{m}^{2}$ numbers as determined before harvest were greatest in wheat monoculture, 177 weeds per surface unit. These numbers decreased significantly in crop rotations as follows: 37 in 2 yr. crop rotations and 23 weeds $/ \mathrm{m}^{2}$ in 3 yr. crop rotations which represents (in \%) 13 and $20.9 \%$ of total number of weeds identified in wheat monoculture $\left(177\right.$ weeds $\left./ \mathrm{m}^{2}\right)$.

- the dominant weed species among monocotyledons was Apera spica-venti and among dicotyledons, Raphanus raphanistrum, Chenopodium album and Matricaria inodora, regardless to crop rotation. There was not reported any distribution pattern of weed species depending on the rotation.

The flower-dwelling composition of monocotyledons and dicotyledons weed species according to the crop rotation under study, Oradea (Romania) 2008-2009

\begin{tabular}{|c|c|c|c|}
\hline \multirow{2}{*}{ Dominant weed species } & \multicolumn{3}{|c|}{ Crop rotation } \\
\hline & Monoculture & $\mathrm{W}-\mathrm{M}$ rotation & $\mathrm{P}-\mathrm{W}-\mathrm{M}$ rotation \\
\hline Monocotyledons & $\begin{array}{c}\text { Wind grass } \\
\text { (Apera spica-venti) }\end{array}$ & $\begin{array}{c}\text { Wind grass } \\
\text { (Apera spica-venti) }\end{array}$ & $\begin{array}{c}\text { Wind grass } \\
\text { (Apera spica-venti) }\end{array}$ \\
\hline \multirow{6}{*}{ Dicotyledons } & $\begin{array}{c}\text { Wild chamomile } \\
\text { (Matricaria inodora) }\end{array}$ & $\begin{array}{l}\text { Wild chamomile } \\
\text { (Matricaria inodora) }\end{array}$ & $\begin{array}{c}\text { Orache } \\
\text { (Chenopodium album) }\end{array}$ \\
\hline & $\begin{array}{c}\text { Wild rape } \\
\text { (Raphanus raphanistrum) }\end{array}$ & $\begin{array}{c}\text { Buckwheat } \\
\text { (Poligonum convolvulus) }\end{array}$ & $\begin{array}{c}\text { Wild rape } \\
\text { (Raphanus raphanistrum) }\end{array}$ \\
\hline & $\begin{array}{c}\text { Buckwheat } \\
\text { (Poligonum convolvulus) }\end{array}$ & $\begin{array}{c}\text { Chickweed } \\
(\text { Stellaria media }) \\
\end{array}$ & $\begin{array}{c}\text { Buckwheat } \\
\text { (Poligonum convolvulus) }\end{array}$ \\
\hline & $\begin{array}{c}\text { Larkspur } \\
\text { (Delphynium consolida) }\end{array}$ & $\begin{array}{c}\text { Orache } \\
\text { (Chenopodium album) }\end{array}$ & $\begin{array}{c}\text { Pelamid } \\
\text { (Cirsium arvense) }\end{array}$ \\
\hline & $\begin{array}{c}\text { Red grass } \\
\text { (Polygonum persicaria) }\end{array}$ & - & $\begin{array}{c}\text { Bindweed } \\
\text { (Convolvulus arvensis) }\end{array}$ \\
\hline & $\begin{array}{c}\text { Chickweed } \\
\text { (Stellaria media })\end{array}$ & - & 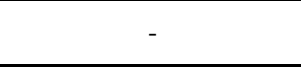 \\
\hline No. of weeds $/ \mathrm{m}^{2}$ & $177(100 \%)$ & $37(20.9 \%)$ & $13.0 \%)$ \\
\hline
\end{tabular}

Legends: $\mathrm{W}=$ wheat; $\mathrm{P}=\mathrm{Pea} ; \mathrm{C}=$.corn.

\section{CONCLUSIONS}

1.The forerunner plants'quality has a positive effect on total biomass accumulation as compared with wheat monoculture, the obtained values being conditioned by a higher favourableness of climatic factors.

2.With regard to biomass accumulation in seeds, it was positively influenced by the quality of the forerunner plant, being higher in correlation with the forerunner plants'better qualities.

\section{REFERENCES}

1. Bandici, Gh., (1997): Contribuții la stabilirea influenței premergătoarei şi a fertilizării asupra dinamicii acumulării biomasei, la grâul de toamnă, cultivat pe soluri cu exces temporar de umiditate, în centrul Câmpiei de Vest a României. Doctoral thesis. University of Agriculture Sciences and Veterinary Medicine Cluj-Napoca, Romania. 
2. Bandici, Gh., Guş, P., (2001): Dinamica acumulării de biomasă la grâul de toamnă. University of Oradea Press. pp.107

3. Chiriță, V., (1983): Influența principalelor măsuri agrofitotehnice asupra dinamicii substanțelor organice ale solului. Probleme de agrofitotehnie teoretică şi aplicată nr. 3, vol. V, pp: 29-32.

4. Hera, C., Chiriță, V., (1986): Influența aerației solului asupra dinamicii substanțelor organice. Cereale şi plante tehnice nr 6. pp.127.

5. Lazany, J., (2000): Soil fertility management in Westik's crop rotation experiment. Role of fertilizers in Sustainable Agriculture. CIEC Conference. pp.77-80.

6. Lazany, J., (2003): Differences in soil carbon content in the treatments of Westik's crop rotation experiment. Natural resources and sustainable development. International scientific session and reviewed papers. OradeaDebrecen, pp. 119-120.

7. Popescu, A., (1980): Procesul de fixare biologic a N atmospheric şi factorii care îl condiţionează. Probleme de agrofitotehnie teoretică şi aplicată, nr. 1, vol. II, pp: 54-57.

8. Staicu, I., (1969): Agrotehnica. Agrosilvică Printing House, Bucharest, 427 p.

9. Zăhan, P., (1972): Influenta unor măsuri agrotehnice aupra îmburuienării şi stării fitosanitare, la grâul cultivat pe un sol acid din nord-vestul Transilvaniei”. An. ICCPT Funduleea, vol. 38, seria B, pp: 67-70. 